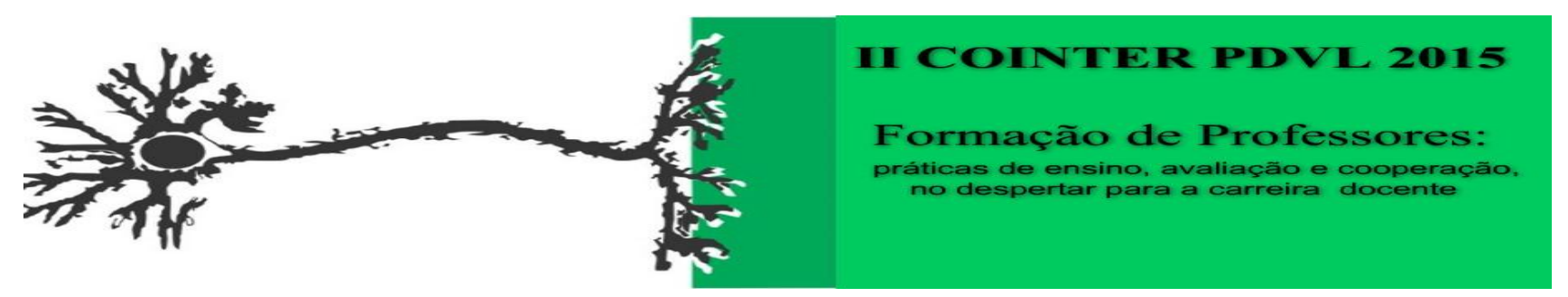

\title{
A IMPORTÂNCIA DA MANUTENÇÃO E EXPANSÃO DO PIBID PARA A FORMAÇÃO DOCENTE E PARA AS ESCOLAS
}

\author{
Apresentação: Relato de Experiência \\ Wanessa Kamily Bezerra dos Santos ${ }^{1}$; Ana Paula Siqueira da Silva ${ }^{2}$; Lígia \\ Cristina Vasconcelos ${ }^{3}$; Tânia Tassinari Rieger ${ }^{4}$
}

\section{Introdução}

Este é um recorte de uma pesquisa realizada pelos acadêmicos/ bolsistas do Subprojeto Biologia do Programa Insttitucional de bolsas de Iniciação à Docência - PIBID programa este que tem como objetivo incentivar a formação de docentes em nível superior para a educação básica;contribuir para a valorização do magistério; elevar a qualidade da formação inicial de professores nos cursos de licenciatura, promovendo a integração entre educação superior e educação básica; inserir os licenciandos no cotidiano de escolas da rede pública de educação, proporcionando-lhes oportunidades de criação e participação em experiências metodológicas, tecnológicas e práticas docentes de caráter inovador e interdisciplinar que busquem a superação de problemas identificados no processo de ensino-aprendizagem; incentivar escolas públicas de educação básica, mobilizando seus professores como coformadores dos futuros docentes e tornando-as protagonistas nos processos de formação inicial para o magistério; e contribuir para a articulação entre teoria e prática necessárias à formação dos docentes, elevando a qualidade das ações acadêmicas nos cursos de licenciatura. Este relato tem como objetivo compreender se a experiência na escola parceira do projeto reflete na formação acadêmica dando ênfase a importância de vivenciar os diversos conflitos presentes no meio escolar. Nesse sentido, faz-se necessário uma reflexão de como a iniciação à docência, através de projetos no início das licenciaturas, influenciam no

\footnotetext{
${ }^{1}$ Ciências Biológicas Licenciatura, UFPE, wanessakamily2009@hotmail.com

${ }^{2}$ Ciências Biológicas Licenciatura, UFPE, anapoliva@hotmail.com

${ }^{3}$ Professora da Rede Estadual de Ensino de Pernambuco, E.R.E.M Diário de Pernambuco, ligiavcris@hotmail.com

${ }^{4}$ Professora Universitária e Coordenadora do Pibid Subprojeto Biologia, UFPE, rieger.tassinari@ufpe.com
} 
desenvolvimento da práxis pedagógica desses futuros profissionais, propiciando a formação continuada durante o percurso acadêmico. Diante disso, faz-se necessário a reflexão das práticas desenvolvidas nos espaços em que elas ocorrem, haja vista, a necessidade da busca por qualificação profissional e a melhoria da educação.

\section{Relato de Experiência}

A pesquisa foi realizada durante o ano de 2015 na E.R.E.M Diário de Pernambuco, uma das escolas parceiras do PIBID, localizada na periferia do município de Recife - PE. Tal pesquisa envolveu acadêmicos/ bolsistas do Subprojeto de Licenciatura em Química, Biologia, Matemática e Física. As bases teóricometodológicas desta pesquisa estão fundamentadas dentro da perspectiva qualitativa com enfoque na pesquisa-ação, pois, não há como desassociar os três componentes básicos da pesquisa: meio, metodologia e pesquisador. Através da metodologia da pesquisa-ação os sujeitos foram instigados a construir a sua própria bagagem de conhecimento, tendo como desafio a superação de dois pontos essenciais: ação e conhecimento. Além disso, entre os métodos utilizados que deram subsídio a esta pesquisa citam-se a observação e a análise crítica do desenvolvimento dos acadêmicos a partir das produções realizadas durante a vivência no projeto.

\section{Considerações}

Através desta pesquisa compreendeu-se que a participação das bolsistas neste projeto é de suma importância para o desenvolvimento acadêmico, tendo em vista, que o PIBID proporciona aos bolsistas uma experiência rica dando embasamento teórico e prático para as experiências que permeiam o contexto escolar. No entanto, cabe ressaltar que nenhuma formação docente dá-se pela neutralidade, mas, sim pelos conflitos existentes nos diversos contextos. Nessa perspectiva, o projeto também tem possibilitado a formação profissional através das produções científicas desenvolvidas no decorrer da trajetória acadêmica, tais como, publicações de artigos, resumos entre outros, participações em eventos e ainda as produções de cunho cultural como, por exemplo: apresentações teatrais e musicais. Sendo assim, as ações como: auxílio em sala de aula, práticas de incentivo à 
leitura, oficinas etc. que foram desenvolvidas durante o projeto propiciou um novo olhar sobre a formação docente, ou seja, a revalorização e um novo conceito sobre o que é ser professor e as implicações diárias enfrentadas por este profissional, sendo este, muitas vezes julgado a partir de um ponto de vista pragmático como elemento secundário no processo educativo tornando a sua atuação reprodutivista e limitada.

Tendo em vista, que a intenção desta pesquisa foi compreender a importância do PIBID na formação acadêmica, pode-se dizer que é fundamental que o discente vivencie a realidade escolar através de projetos de iniciação a docência, pois, a partir dele é possível fazer a aproximação teórica do campo empírico. Nesse contexto, fica evidente que o projeto propicia uma formação diferenciada por meio da prática compensando as lacunas ainda existentes na grade curricular dos cursos de licenciatura. Portanto, a formação acadêmica através do projeto PIBID dá-se de maneira desafiadora e instigante, pois, exige do discente empenho, dedicação e colaboração para a efetuação das atividades propostas. Diante do exposto, a vivência no projeto proporciona incentivos com relação à pesquisa e a formação docente crítica-reflexiva à medida que torna a aprendizagem significativa, baseando-se nos diversos contextos e conflitos, que permeiam o campo educativo. Assim sendo, ressalta-se que é relevante vivenciar, refletir e reconstruir as práticas por intermédio do projeto, compartilhando as idéias e discussões desenvolvidas no período, atendendo a demanda existente em prol da educação emancipadora, significativa e democrática, ou seja, um desafio posto para o professor do século XXI.

\section{Referências Bibliográficas}

HOFFMANN, Jussara. Avaliação mediadora: uma prática em construção da préescola à universidade. 20 ed. Porto Alegre: Editora Mediação, 2003.

LIBÂNEO, José Carlos. Didática. São Paulo, Cortez Editora, 1994. 